\title{
EFFECTS OF TEMPERATURE AND TOMATO VARIETY ON DEVELOPMENT STAGES OF BACTERICERA COCKERELLI (SULC) (HEMIPTERA: TRIOZIDAE)
}

\section{EFECTOS DE LA TEMPERATURA Y VARIEDADES DE TOMATE SOBRE LOS ESTADOS DE DESARROLLO DE BACTERICERA COCKERELLI (SULC) (HEMIPTERA: TRIOZIDAE)}

\author{
HAIDEL VARGAS-MADRIZ ${ }^{1}$, MARÍA GUZMÁN-MARTÍNEZ², JESÚS ALBERTo ACUÑA-SOTOª ${ }^{3}$ AUSENCIO \\ AZUARA-DOMíngUEZ ${ }^{4}$, Pedro Fabián GRIFALdO-ALCÁNTARA ${ }^{1}$, AlFonso LUNA-CRUZ ${ }^{5}$, MarTha \\ OLIVIA LÁZARO-DZUL ${ }^{4 *}$
${ }^{1}$ Centro Universitario de la Costa Sur, Universidad de Guadalajara. Av. Independencia Nacional No. 151. C.P. 48900, Autlán de Navarro, Jalisco, México.<haidel_vargas@hotmail.com>; <fabian.grifaldo@academicos.udg.mx>
${ }^{2}$ Unidad Académica de Matemáticas. Universidad Autónoma de Guerrero. Avenida Lázaro Cárdenas sin número, Ciudad Universitaria, C.P. 39087. Chilpancingo de los Bravo, Guerrero, México.<manguzgm@gmail.com>
${ }^{3}$ División de Ingeniería en Innovación Agrícola Sustentable. TecNM-Tecnológico Superior de Tlatlauquitepec. Carretera Federal Amozoc-Nautla Km. 122 + 600, Almoloni, C.P. 73907, Tlatlauquitepec, Puebla, México. <coleoptero77@ hotmail.com> ${ }^{4}$ TecNM-Instituto Tecnológico de Ciudad Victoria, Postgrado en Biología. Boulevard Emilio Portes Gil No. 1301, C.P. 87010. Victoria, Tamaulipas, México. <azuarad@gmail.com>; <dzulmartha@gmail.com>
${ }^{5}$ Catedrático CONACYT - Universidad Michoacana de San Nicolás de Hidalgo. Instituto de investigaciones químico-biológicas Av. Francisco J. Múgica S/N. Ciudad Universitaria. Morelia, Michoacán, México, C.P. 58030. <alunacr@ conacyt.mx> \\ *Corresponding author: <dzulmartha@gmail.com>
}

Received: 09/02/2019; accepted: 21/03/2020; published online: 25/03/2020 Responsible editor: Arturo Bonet Ceballos

Vargas-Madriz, H., Guzmán-Martínez, M., Acuña-Soto, J. A., Azuara-Domínguez, A., GrifaldoAlcántara, P. F., Luna-Cruz, A., Lázaro-Dzul, M. O. (2020) Effects of temperature and tomato variety on development stages of Bactericera cockerelli (Sulc) (Hemiptera: Triozidae). Acta Zoológica Mexicana (nueva serie), 36, 1-10. https://doi.org/10.21829/azm.2020.3612178

\begin{abstract}
Tomato is one of the most consumed vegetables per capita in the world; it is grown both in the open and in greenhouses. Under these conditions, the pest is considered a severe problem, especially considering Bactericera cockerelli Sulc. Therefore, in this experiment, the life history of this pest insect in two tomato varieties: "Charanda F1" and "Rafaello" the differences in the development stages of the insect, the mean temperatures of two cycles, and the accumulated heat units determined. The work consisted of evaluating the development of the instars of $B$. cockerelli during two crop cycles in both varieties, as well as the accumulation of heat units to differentiate the distinct instars. The insect populations developed in the Rafaello variety had shorter lives and showed a higher death rate of eggs than did those that developed in Charanda F1. The temperature was another determining factor; when the temperature remained low, the insect biological cycle was longer. Likewise, heat units were different between the two varieties; in Rafaello, 598.13 heat units needed while in Charanda F1, only 464.98. The differences may be due to the morphological characteristics of each variety, as the presence of trichomes and oils. Thus, we suggest that these variables studied in future research works.
\end{abstract}

Key words: heat units; control; pest; population; psyllid 
Vargas-Madriz, H., Guzmán-Martínez, M., Acuña-Soto, J. A., Azuara-Domínguez, A., GrifaldoAlcántara, P. F., Luna-Cruz, A., y Lázaro-Dzul, M. O. (2020) Efectos de la temperatura y variedades de tomate sobre los estados de desarrollo de Bactericera Cockerelli (Sulc) (Hemiptera: Triozidae). Acta Zoológica Mexicana (nueva serie), 36, 1-10.

https://doi.org/10.21829/azm.2020.3612178

RESUMEN. El tomate es uno de los vegetales más consumidos per cápita en el mundo; se cultiva tanto en campo abierto como en invernadero. En ambas condiciones de crecimiento, Bactericera cockerelli Sulc es la plaga principal. Por lo tanto, en este experimento se determinaron la historia de vida de este insecto en dos variedades de tomate: "Charanda F1" y "Rafaello", las diferencias en las etapas de desarrollo del insecto, las temperaturas medias de dos ciclos, y las unidades calor acumuladas. El trabajo consistió en evaluar el desarrollo de los estadios de $B$. cockerelli durante dos ciclos de cultivo en ambas variedades, así como la acumulación de unidades calor para diferenciar los distintos estadios. Las poblaciones de insectos desarrolladas en la variedad Rafaello tuvieron ciclos más cortos y mostraron una mayor tasa de mortalidad de huevos que las que se desarrollaron en Charanda F1. La temperatura fue otro factor determinante; cuando esta se mantuvo baja, el ciclo biológico del insecto fue más largo. Así mismo, las unidades calor fueron diferentes entre las dos variedades; en Rafaello, se necesitaron 598,13 unidades calor, mientras que, en Charanda F1 sólo 464,98. Estas diferencias pueden deberse a las características morfológicas de cada variedad, como la presencia de tricomas y aceites. Por lo tanto, sugerimos que estas variables sean estudiadas en otros trabajos de investigación.

Palabras clave: Unidades calor; control; plagas; poblaciones; psílido

\section{INTRODUCTION}

In Mexican horticulture, tomato (Solanum lycopersicum L.) is a primordial crop, it being one of the most consumed vegetables per capita worldwide, as well as one of the most widely grown in greenhouses, both in Mexico and in Europe and the United States of America. The greenhouse tomato production system consists of the use of varieties with an undetermined development type (Resh, 1992; Sánchez-del Castillo et al., 2009). Mexico produces over two million tons, with an estimated value of 15 billion pesos, in a surface area of 50 thousand $\mathrm{h}$ (SIAP, 2016).

However, this crop is attacked by pests that cause severe damages, one of them being Bactericera cockerelli (Liu \& Trumble, 2004). This pest causes toxin type direct and indirect damages (Garzón-Tiznado et al., 2005) and has caused losses in the national production of this vegetable crop (Bujanos et al., 2005). In Mexico, B. cockerelli is one of the most critical pests in tomato, pepper, and potato crops (Vega-Gutiérrez et al., 2008). Since it is a vector of tomato diseases, B. cockerelli has an excellent capacity to increase its population density, as the female can deposit up to 1,400 eggs during its lifecycle (Liu \& Trumble, 2006).

Because of this, high densities of this insect can cause significant damages to tomato crops. Liu et al. (2006) and Servín et al. (2008) mention than among the most relevant problems caused by this insect is its capacity to inject a toxin that causes modifications in the typical coloring of the leaves, turning them yellow or purple. This symptom is known as "psyllid yellows" or "potato purple tip," which causes plant malformation and death. The symptoms in tomato plants include growth stop, the proliferation of new buds, chlorosis, purpling of the leaves, stimulated flowering, and overproduction of small, low-quality fruits. Given this problem, the present work consisted of determining the life history of B. cockerelli instars in the function of two tomato varieties, mean temperatures, and accumulated heat units. 


\section{MATERIALS AND METHODS}

Study Area. Research experiments were carried out from October to December 2016 and, from January to March 2017, in the greenhouse of the Institute of Plant Health of the Colegio de Postgraduados, Campus Montecillo, Texcoco, State of Mexico.

The colony of Bactericera cockerelli. It sowed the seeds of tomato variety Charanda "F1" and "Rafaello" in germination trays for the establishment of the breeding of B. cockerelli. In Mexico, these varieties are the most cultivated by presenting a long period of fructification and post-harvest (Tigchelaar, 1986; MendozaDe Jesus et al., 2010). Subsequently, 31 days after sowing (DDS) selected and transplanted, in a proper manner, 20 plants of each variety in polyethylene bags with two kilograms of the substrate (50\% of Canada Growing Mix 1VM and 50\% of tezontle). Later, the plants placed in the interior of entomological boxes (62 $\mathrm{cm} \times 95 \mathrm{~cm}$ and $95 \mathrm{~cm}$ ) lined with mesh organza. Right away, were put fourth and fifth instar nymphs and raised to $B$. cockerelli by seven generations to $14: 10 \mathrm{~h}$ of light-dark and ambient temperature. The nymphs used in the breeding were collected previously in tomato plants of the "Rio Grande" variety in the greenhouse of Biological Control of the Colegio de Postgraduados. During reproduction, $300 \mathrm{ml}$ of the nutrient solution was applied to each plant per day. The nutrient solution consisted of $500 \mathrm{ml}$ sulfuric acid, ferrous sulfate $75 \mathrm{~g}, 1,200 \mathrm{ml}$ phosphoric acid, $8.4 \mathrm{~kg}$ calcium nitrate, $3.5 \mathrm{~kg}$ potassium nitrate, $4.5 \mathrm{~kg}$ magnesium sulfate, $3 \mathrm{~kg}$ potassium sulfate, $40 \mathrm{~g}$ manganese sulfate, $5 \mathrm{~g}$ zinc sulfate, $5 \mathrm{~g}$ copper sulfate, 50 $\mathrm{g}$ borax for 10,000 liters of water.

Establishment of the experiments. The experiments developed in entomological boxes, previously described, and in tomato plants of the variety "Charanda F1" and "Rafaello" with 31 days. For each variety of tomato, there were three entomological boxes with five floors and 65 adults of $B$. cockerelli. The plants were placed in the entomological boxes. Immediately, the adults set in the plants for $24 \mathrm{~h}$. Adults were removed and counted; the number of eggs present in the leaves were adjusted to 100. Subsequently, every $24 \mathrm{~h}$ were the nymphal stages up to the adult phase were counted. Also, during the process of the experiment, the temperature and humidity was recorded every 30 minutes using an electronic sensor $\left(\mathrm{HOBO}^{\circledR}\right.$ model $\mathrm{H}$ 08-032-08 \# 333699), temperatures ranged from $2^{\circ} \mathrm{C}$ to $40^{\circ} \mathrm{C}$. The substrate, nutrient solution, and care of the tomato plants were similar to the one used in the development of the breeding of B. cockerelli.

Statistical analysis. We used the number of individuals registered to calculate the survival curves $\left(n_{x}\right)$ of the stages of B. cockerelli in 2016 and 2017. The other hand analyzed the behavior of insects and the effect of temperature on the longevity of the population. To measure both parameters, we have taken into account the following factors: stages of B. cockerelli: eggs, nymph one, two, three, four, five, and adult. Like so tomato varieties: Charanda F1 (CF1) and Rafaello (RAF); crop cycles: $\mathrm{C} 1$ and $\mathrm{C} 2$, and the average temperature in cycle one and cycle two: temPC1 and temPC2 respectively. The statistical analysis was a development out with a complete block design in the statistical software (SAS Institute, 2005). The significance of the factors considered were tested through the application of the procedure GLIMMIX with an alpha of 0.05 . To investigate the effect of the four factors in B. cockerelli, we performed a one-way, twoway, and three-way analysis of variance. Tukey's method used for multiple comparisons and contrasts for main effects and interactions. The statistical analysis carried out in the SAS statistical software (SAS Institute, 2005). The GLM procedure used to generate the analysis of variance table and to estimate and to test contrast.

Finally, we analyzed the behavior of the psyllid through heat units per cycle and tomato varieties using the method of average temperature (Herms, 2004; Sridhar \& Reddy, 2013). The parameter evaluated was, the unit's heat of the nymphal stages of $B$. cockerelli, and were calculated using the following formula: $\mathrm{HU}=\left(\mathrm{T}^{\circ} \mathrm{C}\right.$ mín. $+\mathrm{T}^{\circ} \mathrm{C}$ máx. $) / 2-7^{\circ} \mathrm{C}$

Where: $\mathrm{HU}=$ Heat Units 
$\mathrm{T}^{\circ} \mathrm{C} \min =$ Minimum temperature

$\mathrm{T}^{\circ} \mathrm{C} \max =$ Maximum temperature

Moreover, $7^{\circ} \mathrm{C}$ corresponds to the minimum temperature threshold of development of $B$. cockerelli (González-Maldonado \& García-Gutiérrez, 2012).

The development of the psyllid through heat units was analyzed, first between the two crop cycles and then comparing between the two tomato varieties. The $t$-test in the INFOSTAT statistical software was used (UNC, 2013).

\section{RESULTS}

In the first crop cycle, the $B$. cockerelli populations, it was noted to have a shorter lifespan in the CF1 in comparison with the populations present in the RAF. In the RAF, higher mortality in the development of nymphs one and three, the average mortality of eggs, and lower mortality of adults were observed (Fig. 1). Nevertheless, in the second crop cycle, in the number one entomological box of CF1, high mortality was obtained in the nymph five and adult. Contrary to what obtained inside the RAF growth chamber number 2, where the results revealed that all stages of the insect suffered from higher mortality compared to the remaining chambers (Fig. 1).
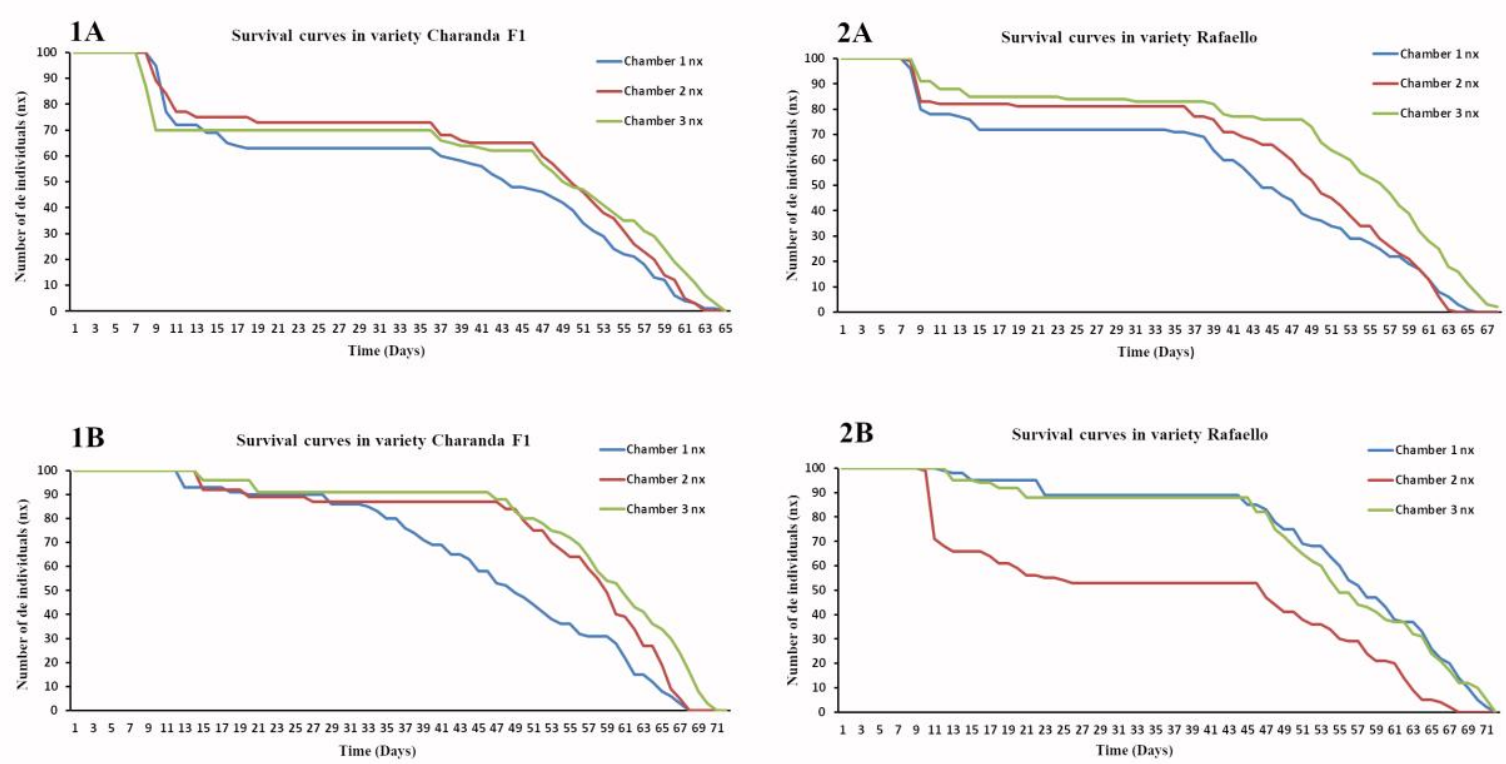

Figure 1. Survival curves $\left(\mathrm{n}_{\mathrm{x}}\right)$ of $B$. cockerelli in the tomato varieties Charanda F1 (1A and 1B) and Rafaello (2A and 2B) grown in the greenhouse during October-December 2016 (1A and 2A) - January-March 2017 (1B and 2B).

In the development analysis of B. cockerelli instars, the factors: cycle, variety, and instar, as well as the interactions: cycle-variety and cycle-instar, explained the biological cycle of the insect. In the mentioned factors, the biological cycle of the insects in $\mathrm{C} 1$ observed to be significantly different from that of $\mathrm{C} 2$ (Table 1). About temperature per cycle, Table 2 shows that insect survival was higher in $\mathrm{C} 2$ than in $\mathrm{C} 1$.

Table 3 shows the temPC1-CF1 interaction significantly affects the longevity of the insect. The lifespan of the insect was less than $21^{\circ} \mathrm{C}$, while, as temperature decreased $\left(19^{\circ} \mathrm{C}\right)$, the insects increased its lifespan in the same variety. Contrastingly, this behavior not observed in the RAF variety. 
Table 1. Three-way of variance table for B. cockerelli in the greenhouse (October-December 2016 and January-March 2017).

\begin{tabular}{cccccc}
\hline Source of variation & Degrees of freedom & Sum of the squares & Mean square & $\boldsymbol{F}$-value & $\boldsymbol{P}$-value \\
\hline Cycle & 1 & 1226.67 & 1226.6 & 26.61 & $<0.0001$ \\
Variety & 1 & 192.01 & 192 & 4.17 & 0.0451 \\
Instar & 6 & 5930.61 & 988.4 & 21.44 & $<0.0001$ \\
Cycle*Variety & 1 & 520.01 & 520 & 11.28 & $<0.0013$ \\
Cycle*Instar & 6 & 619.90 & 103.3 & 2.24 & 0.0494 \\
\hline
\end{tabular}

On the other hand, the C1-CF1 interaction significantly affects the longevity of the insect population compared against the other interactions in both cycles (Table 4). The insect longevity in the CF1 variety in $\mathrm{C} 1$ was lower at $21^{\circ} \mathrm{C}$, while as the temperature decreased to $19^{\circ} \mathrm{C}$, there was an increase in the longevity of the insect in the same variety. This behavior not observed in the RAF variety. From instar two to instar five, the lifecycle of the insect is affected by the mean temperature of the crop cycle. In Cycle 1, the development of the mentioned nymph instars was affected (Table 5). Delimitation of the heat units required for the development of the stages of $B$. cockerelli in two tomato varieties.

Table 2. Means comparison of temperatures of both cycles for the behavior of $B$. cockerelli grown in two tomato varieties in the greenhouse (October-December 2016 and January-March 2017).

\begin{tabular}{cccc}
\hline temPC & No. of observations & Means & $P$-value \\
\hline TemPC1 & 42 & $21.30 \mathrm{a}$ & $<0.0001$ \\
temPC2 & 42 & $19.38 \mathrm{~b}$ & $<0.0001$ \\
\hline
\end{tabular}

tempPC1 = mean temperature in Cycle 1 , temPC2 $=$ mean temperature in Cycle 2, means with the same letter are statistically equal, Tukey $(P<0.05)$.

Table 3. Means comparison of the temPC*variety interaction of the biological cycle of $B$. cockerelli grown in two tomato varieties in the greenhouse (October-December 2016 and January-March 2017).

\begin{tabular}{cccccc}
\hline Interactions & No. of observations & Means & $\boldsymbol{T}$-value & $\boldsymbol{P}$-value & $\begin{array}{c}\text { Mean } \\
\text { temperature } \\
\left({ }^{\circ} \mathbf{C}\right)\end{array}$ \\
\hline temPC2*Charanda F1 & 21 & $89.9 \mathrm{a}$ & 60.68 & $<0.0001$ & 19.38 \\
temPC2*Rafaello & 21 & $87.9 \mathrm{a}$ & 59.36 & $<0.0001$ & 19.38 \\
temPC1*Rafaello & 21 & $85.2 \mathrm{a}$ & 57.56 & $<0.0001$ & 21.30 \\
temPC1 ${ }^{*}$ Charanda F1 & 21 & $77.2 \mathrm{~b}$ & 52.16 & $<0.0001$ & 21.30 \\
\hline
\end{tabular}

temPC1 = mean temperature in Cycle 1, temPC2 = mean temperature in Cycle 2, means with the same letter are statistically equal, Tukey $(P<0.05)$.

Table 4. Means comparison of the cycle*variety interaction of the biological cycle of B. cockerelli grown in two tomato varieties in the greenhouse (October-December 2016 and January-March 2017).

\begin{tabular}{ccccc}
\hline Interactions & No. of observations & Means & $\boldsymbol{P}$-value & Mean temperature $\left({ }^{\circ} \mathbf{C}\right)$ \\
\hline Cycle $1 *$ Charanda F1 & 21 & $77.2 \mathrm{~b}$ & $<0.0001$ & 21.30 \\
Cycle $1 *$ Rafaello & 21 & $85.2 \mathrm{a}$ & $<0.0001$ & 21.30 \\
Cycle $2 *$ Charanda F1 & 21 & $89.9 \mathrm{a}$ & $<0.0001$ & 19.38 \\
Cycle 2*Rafaello & 21 & $87.9 \mathrm{a}$ & $<0.0001$ & 19.38 \\
\hline
\end{tabular}

Means with the same letter are statistically equal, Tukey $(P<0.05)$. 
The accumulated HU from egg to nymph 1 differed statistically in both crop cycles for the CF1 variety; $\mathrm{HU}$ was needed in the 2009 cycle to differentiate nymph $1(F=16.0, P=0.01)$. In the rest of the instars, there were no significant differences between one cycle and the other (Table 6).

The accumulated HU in the RAF from egg to nymph was the same; there was no significant difference between both crop cycles. However, from nymph two to nymph three, and from four to five, there were significant differences in their development in both crop cycles, the test showed no significant differences. The two crop cycles differed statistically; more heat units were needed in the 2009 cycle to identify nymph 1 . There were no significant differences between cycles regarding the rest of the instars (Table 7).

When analyzing the accumulated heat units data, considering the heat units means per cycles and variety, significant differences in both varieties $(F=20.23, P=0.001)$ only found from nymph three to nymph four; there were no significant differences in the rest of the instars (Table 8). So, in general, in both varieties, the heat unit accumulation was the same from egg to adult.

Table 5. Effect of the comparison of temPC*instar minimum mean square of $B$. cockerelli lifespan in two tomato varieties grown in the greenhouse (October-December 2016 and January-March 2017).

\begin{tabular}{|c|c|c|c|c|c|}
\hline Stages & Effect & No. of observations & Minimum Mean squares & $T$-value & $P$-value \\
\hline Adult & temPC2 vs temPC1 & 12 & 6.3 & 1.62 & 0.1108 \\
\hline Egg & temPC2 vs temPC1 & 12 & -79 & 0.00 & 1.0000 \\
\hline Nymph 1 & temPC2 vs temPC1 & 12 & -0.1 & -0.04 & 0.9662 \\
\hline Nymph 2 & temPC2 vs temPC1 & 12 & 11.5 & 2.93 & 0.0046 \\
\hline Nymph 3 & temPC2 vs temPC1 & 12 & 14.6 & 3.74 & 0.0004 \\
\hline Nymph 4 & temPC2 vs temPC1 & 12 & 12 & 3.06 & 0.0032 \\
\hline Nymph 5 & temPC2 vs temPC1 & 12 & 9.1 & 2.34 & 0.0223 \\
\hline
\end{tabular}

temPC1 $=$ mean temperature in Cycle 1, temPC2 $=$ mean temperature in Cycle 2.

Table 6. Biological development of $B$. cockerelli chronologically (days) and physiologically (heat units) in the Charanda F1 variety in 2016 and 2017 cycles, grown under greenhouse conditions.

\begin{tabular}{|c|c|c|c|c|c|c|c|}
\hline \multirow{2}{*}{ Instar } & \multirow{2}{*}{$P$-value } & \multirow{2}{*}{$\mathbf{F}$} & \multirow{2}{*}{ gl } & \multicolumn{2}{|c|}{ Sample size } & \multicolumn{2}{|c|}{ HU duration $\left(\mathrm{SE}^{1}\right)$} \\
\hline & & & & 2016 & 2017 & 2016 & 2017 \\
\hline Egg-Nymph1 & 0.01 & 16.00 & 4 & 245 & 280 & $107.21 \pm 6.9$ & $94.75 \pm 0.0$ \\
\hline Nymph1- Nymph2 & 0.21 & 2.22 & 4 & 172 & 269 & $64.85 \pm 5.0$ & $167.74 \pm 9.0$ \\
\hline Nymph2- Nymph3 & 0.55 & 0.40 & 4 & 126 & 220 & $55.52 \pm 10.5$ & $107.56 \pm 7.8$ \\
\hline Nymph3- Nymph4 & 0.88 & 0.02 & 4 & 92 & 139 & $62.67 \pm 10.6$ & $77.30 \pm 11.7$ \\
\hline Nymph4- Nymph5 & 0.50 & 0.53 & 4 & 86 & 117 & $123.28 \pm 17.0$ & $64.57 \pm 11.0$ \\
\hline Nymph5-Adult & 0.99 & 0.00 & 4 & 67 & 111 & $102.01 \pm 7.2$ & $82.52 \pm 7.2$ \\
\hline Total & & & & & & 453.39 & 594.44 \\
\hline
\end{tabular}

${ }^{1} \mathrm{SE}=$ Standard error.

\section{DISCUSSION}

The survival curves of $B$. cockerelli were similar in both crop cycles, and for each insect cycle, there being mortality in nymphs one to three. Similar results reported by Davis (1937), Liu and Trumble (2006), and Yang and Liu (2009). These authors mention that the highest mortality of nymphs happens from the first to third instars. 
On the other hand, in the tomato variety and B. cockerelli instars, the biological cycle of the insects in $\mathrm{C} 1$ was found to be significantly different from those in C2. This behavior is as that reported by Yang and Liu (2009), Yang et al. (2010), and Vargas-Madríz et al. (2011), who mention that the host plants where $B$. cockerelli grows significantly influence the biological parameters.

The temPC-variety and cycle-variety interactions significantly affected the longevity of the insect populations; this is, the insect longevity was lower at a temperature of $21^{\circ} \mathrm{C}$. Although, when the temperature lowered to $19^{\circ} \mathrm{C}$, there was an increase in insect longevity in the same variety. These results coincide with those by List (1939) and Pavlista (2002), who mentions that temperature is a critical factor for the development of populations of this insect, with an optimum development being at temperatures of $27^{\circ} \mathrm{C}$. At higher temperatures, the eggs and nymphs can be affected. Moreover, Lehman (1930) mention that field populations of $B$. cockerelli are particularly abundant after warm winters and fresh environments. The time required for the development of one generation from egg to adult is 15 to 10 days. The optimum temperature for their development is $27^{\circ} \mathrm{C}$, while temperatures below $15^{\circ} \mathrm{C}$ or over $32^{\circ} \mathrm{C}$ affect their development and survival.

Table 7. Biological development of B. cockerelli chronologically (days) and physiologically (heat units) in Rafaello tomato variety in cycles 2016 and 2017, grown under greenhouse conditions.

\begin{tabular}{cccccccc}
\hline Instar & \multirow{2}{*}{$\boldsymbol{P}$-value } & \multirow{2}{*}{ F } & gl & \multicolumn{2}{c}{ Sample size } & \multicolumn{2}{c}{ HU duration (SE $\left.\mathbf{S E}^{\mathbf{1}}\right)$} \\
& & & & $\mathbf{2 0 1 6}$ & $\mathbf{2 0 1 7}$ & $\mathbf{2 0 1 6}$ & $\mathbf{2 0 1 7}$ \\
\hline Egg - Nymph1 & 0.01 & 16.00 & 4 & 236 & 274 & $121.14 \pm 0.0$ & $112.23 \pm 0.0$ \\
Nymph 1- Nymph 2 & 0.21 & 2.22 & 4 & 234 & 248 & $58.85 \pm 9.9$ & $166.0 \pm 16.2$ \\
Nymph 2 - Nymph 3 & 0.55 & 0.40 & 4 & 209 & 139 & $84.1 \pm 0.0$ & $128.01 \pm 8.2$ \\
Nymph 3 - Nymph 4 & 0.88 & 0.02 & 4 & 111 & 121 & $145.39 \pm 0.0$ & $57.94 \pm 10.0$ \\
Nymph 4 - Nymph 5 & 0.50 & 0.53 & 4 & 106 & 100 & $42.75 \pm 14.3$ & $33.28 \pm 0.6$ \\
Nymph 5 - Adult & 0.99 & 0.00 & 4 & 73 & 88 & $146.7 \pm 7.1$ & $99.85 \pm 5.1$ \\
Total & & & & & & 598.94 & 597.38 \\
\hline
\end{tabular}

${ }^{1} \mathrm{SE}=$ Standard error.

Heat units have been studied in a great variety of insects, among which is the whitefly, with optimum, maximum, and minimum values for thermal requirements for its development, varying between species and from one instar to another. In the case of Bemisia tabaci (Gennadius), the cited minimum and maximum temperature thresholds are $11^{\circ} \mathrm{C}$ and $33^{\circ} \mathrm{C}$, respectively, while the highest development rate is at $28^{\circ} \mathrm{C}$. B. tabaci in cotton crops in the La Laguna region, Mexico, needs 275 heat units (HU = GDD) and a base temperature (bT) of $12^{\circ} \mathrm{C}$. However, other researchers mention that this species needs 315 thermal units $(\mathrm{TU}=\mathrm{GDD})$ to complete its cycle, and a bT of $10^{\circ} \mathrm{C}$ (Ortiz et al., 2010).

Bactericera cockerelli shows a tendency like a whitefly. Several researchers have studied and determined different heat units for the development of B. cockerelli. For example, González-Maldonado and García-Gutiérrez (2012) indicate that the cycle of this insect is completed with $356 \mathrm{HU}$, while Ramírez et al. (2008) mention $336 \mathrm{HU}$. Likewise, Becerra (1989) determined, under laboratory conditions, the $B$. cockerelli completed its biological cycle with $335.8 \mathrm{HU}$ and a threshold temperature of $7^{\circ} \mathrm{C}$. In the present research, the lifecycle of B. cockerelli completed with 464.98 and $598.13 \mathrm{HU}$ in the CF1 and RF, respectively. Perhaps this difference is because incubation ranges from three to 15 days, depending on temperature (Pletsch, 1947).

For its part, Vaishampayan and Kogan (1980) state that the lifecycle of sweet potato whitefly, $B$. tabaci, can decrease its biological cycle when it develops on sick plants. This information opens the possibility that heat units are not only affected by temperature but also by other factors like the 
morphological condition of the plant, its nutritional state, and its general health. It suggested that the difference between varieties in this research might have been due to one of these mentioned conditions.

According to results, it concluded that the development of B. cockerelli on both tomato varieties is affected by the mean temperatures registered during the time of both crop cycles, and by the heat units observed for this insect. Another factor to consider could be the morphological characteristics of each variety, and the presence of trichomes and oils.

Table 8. Accumulation of heat units in B. cockerelli in two tomato varieties: Charanda F1 and Rafaello, in two crop cycles.

\begin{tabular}{|c|c|c|c|c|c|}
\hline \multirow[b]{2}{*}{ Stages } & \multirow[b]{2}{*}{$P$-value } & \multirow[b]{2}{*}{$\mathbf{F}$} & \multirow[b]{2}{*}{ gl } & \multicolumn{2}{|c|}{ Mean $\left(\mathrm{SE}^{\mathbf{1}}\right)$} \\
\hline & & & & $\begin{array}{l}\text { Charanda F1 } \\
\text { (Sample size) }\end{array}$ & $\begin{array}{c}\text { Rafaello } \\
\text { (Sample size) }\end{array}$ \\
\hline Egg - Nymph1 & 0.454 & 0.608 & 10 & $\begin{array}{c}100.98 \pm 4.17 \\
(525)\end{array}$ & $\begin{array}{c}116.68 \pm 1.99 \\
(510)\end{array}$ \\
\hline Nymph1 - Nymph2 & 0.828 & 0.050 & 10 & $\begin{array}{c}116.29 \pm 23.46 \\
(441)\end{array}$ & $\begin{array}{c}112.45 \pm 25.44 \\
(482)\end{array}$ \\
\hline Nymph2 - Nymph3 & 0.566 & 0.352 & 10 & $\begin{array}{c}81.54 \pm 13.00 \\
(346)\end{array}$ & $\begin{array}{c}106.06 \pm 10.48 \\
(348)\end{array}$ \\
\hline Nymph3 - Nymph4 & 0.001 & 20.23 & 10 & $\begin{array}{c}69.98 \pm 7.82 \\
(231)\end{array}$ & $\begin{array}{c}101.66 \pm 20.06 \\
(232)\end{array}$ \\
\hline Nymph4 - Nymph5 & 0.108 & 3.10 & 10 & $\begin{array}{c}93.92 \pm 16.06 \\
(203)\end{array}$ & $\begin{array}{c}38.015 \pm 6.75 \\
(206)\end{array}$ \\
\hline Nymph5 - Adult & 0.052 & 4.85 & 10 & $\begin{array}{l}92.27 \pm 6.33 \\
\quad(178)\end{array}$ & $\begin{array}{c}123.27 \pm 11.19 \\
(161)\end{array}$ \\
\hline Total heat units & & & & 464.98 & 598.13 \\
\hline
\end{tabular}

${ }^{1} \mathrm{SE}=$ Standard error.

\section{LITERATURE CITED}

Becerra, F. A. (1989) Biología de Paratrioza cockerelli (Sulc) y su relación con la enfermedad "permanente del tomate" en el Bajío. Tesis de Licenciatura. Universidad Autónoma de Querétaro, Facultad de Química, Querétaro, México, 55 pp.

Bujanos, M. R., Garzón, T. J. A., Marín, J. A. (2005) Manejo integrado del pulgón saltador Bactericera (=Paratrioza) cockerelli (Sulc.) (Hemiptera: Triozidae) en los cultivos de solanáceas en México. Pp. 93-99. In: Segunda convención mundial del chile. Zacatecas, México.

Davis, A. C. (1937) Observations on the life history of Paratrioza cockerelli (Sulc) in southern California. Journal of Economic Entomology, 30, 377-378.

Garzón-Tiznado, J. A., Garzón-Ceballos, J. A., Velarde-Félix, S., Marín-Jarillo, A., CárdenasValenzuela, O. (2005) Ensayos de transmisión del fitoplasma asociado al "Permanente del tomate" por el psílido Bactericera cockerelli Sulc., en México. Entomología mexicana, 4, 672-675.

González-Maldonado, M. B., García-Gutiérrez, C. (2012) Use of biorational for the vegetable pest control in the north of Sinaloa. Ra Ximhai, 8, 31-46.

Herms, D. A. (2004) Using degree-days and plant phenology to predict pest activity. Pp: 49-59. In: V. Kriscik, J. Davidson (Eds.). IPM (Integrated Pest Management) of midwest landscapes. Regents of the University of Minnesota. Minnesota Agricultural Experiment Station Publication SB-07645.

Lehman, S. S. R. (1930) Some observations on the life history of the tomato psyllid (Paratrioza cockerelli Sulc.) (Homoptera). Journal of the New York Entomological Society, 38 (3), 307-312. 
List, G. M. (1939) The effect of temperature upon egg deposition, egg hatch, and nymphal development of Paratrioza cockerelli (Sulc). Journal of Economic Entomology, 32, 30-36.

Liu, D. J. L., Trumble, J. T. (2004) Tomato psyllid behavioral responses to tomato plant lines and interactions of plant lines with insecticides. Journal of Economic Entomology, 97 (3), 1078-1085.

Liu, D. J. L., Trumble, T. J. (2006) Differential responses to feeding by the tomato/potato psyllid between two tomato cultivars and their implications in the establishment of injury levels and potential of damaged plant recovery. Insect Science, 13, 195-204. https://doi.org/10.1111/j.1744-7917.2006.00082.x

Liu, D. J. L., Trumble, J. T., Stouthamer, R. (2006) Molecular characterization indicates recent introductions of potato psyllid (Bactericera cockerelli) into western North America are genetically different from eastern populations. Entomologia Experimentalis et Applicata, 118, 177-183.

Mendoza-De Jesús, V., Sahagún-Castellanos, J., Rodríguez-Pérez, J. E., Legara-Solano, J. P., PeñaLomelí, A., Pérez-Grajales, M. (2010) Heterosis intervarietal en jitomate de crecimiento indeterminado tipo saladete. Revista Chapingo, Serie Horticultura, 16 (1), 57-66.

Ortiz, M. C., Medina, R. T., Valdivia, R. B., Alvarado, S. C., Rodríguez, R. B. (2010) Mosquitas blancas plaga primaria de hortalizas en Nayarit. Revista Fuente, 2, 31-40.

Pavlista, A. D. (2002) Potato (tomato) psyllids. Nebraska Potato Eyes, 14, 1-4.

Pletsch, D. J. (1947) The potato psyllid Paratrioza cockerelli (Sulc), its biology and control. Bulletin/Montana Agricultural Experiment Station, 446, 1-95.

Ramírez, G. M., Santamaria, E. C., Mendez, R. J. S., Rios, F. J. L., Hernandez, S. J. R., Méndez, J. G. P. (2008) Alternative insecticides evaluation for Paratrioza (Bactericera cockerelli B. and L.) control in a jalapeño pepper (Capsicum annum L.) Cultivar. Revista Chapingo, Serie Zonas Áridas, 76, 47-58.

Resh, H. M. (1992) Cultivos Hidropónicos. $3^{\text {a }}$ Ed. Ediciones Mundi-Prensa. Madrid, España, LIV + 558 pp.

Sánchez-del Castillo, F., Moreno-Pérez, E. del C., Cruz-Arellanes, E. L. (2009) Producción de jitomate hidropónico bajo invernadero en un sistema de dosel en forma de escalera. Revista Chapingo, Serie Horticultura, 15 (1), 67-73.

SAS Institute (2005) SAS for Windows Ver. 9.1 SAS Institute. - Cary, N.J., USA.

Servín, R., Tejas, A., Cota, A. (2008) Primer Reporte de Bactericera cockerelli Sulc, en Plantaciones Hortícolas de Baja California Sur, México. Southwestern Entomologist, 3, 239-241.

Sistema de Información Agrícola y Pecuaria (SIAP) (2016) Producción agrícola por cultivo y por estado. México. Available online: http://www.siap.gob.mx/cierre-de-la-produccion-agricola-porcultivo/\%20 (accessed on November 2017).

Sridhar, V., Reddy, P. V. R. (2013) Use of Degree Days and Plant Phenology: A Reliable Tool for Predicting Insect Pest Activity Under Climate Change Conditions. In: H. C. P. Singh, K. Shivashankara, Nk Rao (Eds.). Climate-Resilient Horticulture: Adaptation and Mitigation Strategies. Springer Science \& Business Media.

Tigchelaar, E. C. (1986) Tomato Breeding. Pp: 135-171. In: M. J. Bassett (Ed.). Avi Breeding Vegetable Crops, Publishing Company. Westport, Connecticut.

Universidad Nacional de Córdoba (UNC) (2013) InfoStat software estadístico. Available online: http://www.infostat.com.ar/ (accessed on November 2017).

Vaishampayan, S. M., Kogan, M. (1980) Sampling whiteflies on soybeans. Pp; 305-311. In: M. Kogan, D. C. Herzog (Eds.). Sampling methods in Entomology, Springer-Verlag, New York.

Vargas-Madriz, H., Bautista-Martínez, N., Vera-Graziano, J., García-Gutiérrez, C., ChavarínPalacio, C. (2011) Life and fertility table of Bactericera cockerelli (Sulc) on two varieties of tomato in a Greenhouse. Southwestern Entomologist, 36 (4), 413-422.

http://dx.doi.org/10.3958/059.036.0403

Vega-Gutiérrez, M. T., Rodríguez-Maciel, J. C., Díaz-Gómez, O., Bujanos-Muñiz, R., Mota-Sánchez, D., Martínez-Carrillo, J. L., Lagunes-Tejeda, A., Garzón-Tiznado, J. A. (2008) Susceptibilidad 
Vargas-Madríz et al.: Effects on development stages of Bactericera cockerelli

a insecticidas en dos poblaciones mexicanas del salerillo, Bactericera cockerelli (Sulc) (Hemiptera: Triozidae). Agrociencia, 42 (4), 463-471.

Yang, X. B., Liu, T. X. (2009) Life history and life tables of Bactericera cockerelli (Homoptera: Psyllidae) on eggplant and bell pepper. Environmental Entomology, 38 (6), 1661-1667.

Yang, X. B., Zhang, Y. M, Hua, L., Tong-Xian, L. (2010) Life history and life tables of Bactericera cockerelli (Hemiptera: Psyllidae) on potato under laboratory and field conditions in the Lower Rio Grande Valley of Texas. Journal of Economic Entomology, 103 (5), 1729-1734.

https://doi.org/10.1603/EC10083 